\title{
COMPETITION POLICY FOR AN ECONOMICALLY INTEGRATED NORTH AMERICA
}

\author{
Peter C. Carstensen*
}

Any effort to achieve substantial North American economic integration must account for and reconcile the varying policies toward competition among the participant countries. Such an undertaking requires at the outset the resolution of two issues fundamental to economic policy. First, there must be a choice between market and nonmarket systems of organizing the major sectors of the economy. ${ }^{1}$ Second, if a market system is chosen, there must be a choice of the degree and method of controlling and directing the market. The alternatives (not entirely mutually exclusive) range from no control beyond that which inheres in such general law as that of contract, to direct performance-oriented control such as specific safety or wage and price controls, to indirect market structure and conduct regulations which seek to achieve social objectives by perfecting the conduct of market activity.

Assuming that markets emerge as important organizing forces for economic activity and that regulation of competition is a primary means of controlling market behavior, there is still a wide variety of specific choices in implementing such a competitive policy. The primary emphasis of this article is on identifying the choices that the United States, Mexico and Canada have made, and to propose ways in which those choices could be reconciled.

The first section of this article explores briefly the relative roles which America, Canada and Mexico assign to market and nonmarket economic activity and the choices these countries have made between direct regulation of market activity and the indirect regulation which antitrust law provides. The second section examines the substantive law of competition as it exists in the three countries and suggests possible ways to reconcile the differing choices that emerge. The final section deals with the most difficult problems of antitrust policy: enforcement methods including the role of private litigation, and the jurisdictional and preemption questions that arise among the participant countries.

Copyright (c) 1981 by Law and Contemporary Problems.

* Professor, University of Wisconsin Law School. The author wishes to thank Jonathan Bernstein lor his assistance in the preparation of this article.

1. For a fuller discussion of the choices see C. Lindblom, Polirics and MakkEts (1977) 


\section{I}

\section{The Role of the Market in Economic Activity and the Methods of Regulating MaRket ACTIVITY}

All three countries employ the market as the basic tool for organizing most productive economic activity. Consequently nonmarket, economic activity is a small sector of the three economies. ${ }^{2}$

The choice of market over other methods of economic allocation does not mean that ownership of enterprises cannot be in public or cooperative entities. ${ }^{3}$ A market approach implies only that buyers and sellers, interacting in a market, however structured, play a substantial role in economic decision-making through voluntary transactions.

All three countries have publicly and cooperatively owned business enterprises. Mexico has the largest concentration of public ownership with some sectors (e.g. , petroleum $)^{4}$ almost entirely so controlled, while other sectors (e.g. , steel) ${ }^{5}$ have substantial and growing private sectors. Canada also has a large and expanding publicly owned sector. Through its investment board Canada has purchased control of a number of corporations doing business in that country. ${ }^{6}$ The Canadian government is presently proposing to obtain significant ownership interests in the domestic petroleum industry. " Several Canadian provinces have also begun to acquire enterprises. ${ }^{8}$ The scope of public ownership in the United States is much less, but many public utility enterprises are publicly owned (e.g. , The Tennessee Valley Authority). A few states also own business enterprises. ${ }^{9}$

All three countries exercise some control over the right of foreigners to own businesses. Both Mexico and Canada have fairly general controls. ${ }^{10}$ The American restrictions historically have focused upon specific industries (e.g., telecommu-

2. Some significant nonmarket activity exists in all three economies. Thus, provision of, e.g., education, some forms of health care, and basic municipal services, occurs on a basis independent of market demand. Political decisions determine the level of output and the allocation of the resulting supply.

3. In general, even when an industry is publicly owned, market demand sets its production level and allocates that production among consumers. Similarly, inputs are obtained in market transactions which require the payment of market price. To be sure subsidies, tax breaks, etc., can and will affect the prices of both inputs and outputs. Such fiddling with the market system is in no way a rejection of or substitution for the market, however much it may be a distortion of it. Rather, such conduct rests on the premisc that the objective is to encourage (or discourage) voluntary market transactions which are mutually satisfactory to the parties.

4. Law for the Promotion of Mexican Investnent and the Regulation of Foreign Investment, ch. 1, art. 4(a) and (b) (English translation in UNITED NATIONS CONFERENCE ON TRADE AND DEVELOPMENT, Control of Restrictive Business Practices in Latin Americ:a Addendum 124-33 (1975)) [hereinafter cited as Foreign Investment Code].

5. Bennett \& Sharpe, The State as Banker and Entrepenuer, 12 CoMP. PoL. 165, $176-77$ (1980).

6. See, e.g., Texasgulf Inc. v. Canada Dev. Corp., 366 F. Supp. 374 (S.D. Tex. 1973).

7. See Urquhardt, Nationalism in Ottawa Perils U.S. Investment in Energy, Other Areas, Wall St. J., Feb. 18, 1981, at 1, col. 6; Meyer, Trudeau's War on U.S. Business, FoRTUNE Apr. 6, 1981, at 74.

8. Quebec, e.g., has recently received final judical clearance to take over the assets in Quebec of $A$ sbestos Corp., Wall St. J., March 18, 1981, at 48, col. 4.

9. An example is the Bank of North Dakota. See Allardice, Stale-Ouned Banks: New Wine for Old Botlles, in Feideral Reserve. Bank of Chicacio, Business Conditions 3 (July 1976).

10. See Foreign Investment Code, supra note 4 (Mexican law); Foreign Investment Review Act, ch. 46, (Acts of Parliament, 1st Sess. 29th Parliament (1974) (Canadian law) [hercinafter cited as Foreign Investment Act]. See also Meyer, supra note 7. 
nications), where public interest concerns were greatest." All three countries also share a common perspective that the government must regulate the market in some way. This commitment and its implementation are strongest in the United States and Mexico.

Canada, while professing to regulate competition, employs statutes demonstrably ineffective for that task. ${ }^{12}$ In consequence, significant anticompetitive behavior has occurred, sometimes aided by public officials. ${ }^{13}$ Moreover, the Canadian government has not undertaken pervasive performance regulation of the market.

The United States has the strongest commitment to regulation of its market via indirect methods. Its antitrust laws cover almost all major aspects of market behavior. While such market structuring regulation is the preferred American alternative, it is not the only method employed. For instance, there is substantial performance regulation. Some is aimed at industries such as public utilities, which are assumed to be monopolistic and hence not amenable to competitive interaction. Other regulation controls competitive markets for matters in which the assumption is, implicitly or explicitly, that market transactions will not produce socially desirable outcomes. Such regulation ranges from environmental controls to the conditions of warranties for consumer goods. ${ }^{14}$ Controls over wages and prices have been implemented in wartime and again during the early 1970s. ${ }^{15}$ The rationale for such controls is that, under some conditions (e.g., war), the market cannot handle its allocation tasks because of massive disequalibrium, or that the expected competitive limitation on exploitation of market position did not occur because of market failures of one kind or another. ${ }^{16}$

The Mexican market economy is the object of substantial performance regulation, especially regarding prices. ${ }^{17}$ At the same time, the Mexican Constitution both prohibits private monopoly and market control and endorses the ideal of competitive market conduct and structure. ${ }^{18}$ The statute ${ }^{19}$ which implements this

11. 47 U.S.C. $\$ 310$ (1962 \& Supp. 1981) (no ownership of radio or television stations).

12. See Canadian Competition Policy: Essays in Law and Economicis (J. Prichard, W. Stanbury, T. Wilson, eds. 1979) [hereinafter cited as Canadian COMPETITION POLICY].

13. United States v. AMAX, Inc., 1977-1 Trade Cas. (CCH) 61,467 (D.C. Ill. 1977) (price fixing in potash not illegal because done at behest of Saskatchewan government). Cf. In Re Uranium Antitrust Litigation, 617 F.2d 1248, 1254 n.21. (7th Cir. 1979).

14. See Magnuson-Moss Warranty Act of 1975, Pub. L. \#93-637, 88 Stat. 2183 (current version at 15 U.S.C. $\S 45$ et seq., (1976)); Environmental Quality Improvement Act of 1970, Pub. L. No. 91-224, 84 Stat. 114, 42 U.S.C. $\$ 4371$ et seq. Cf. Stone, The Place of Enterprise Liability in the Control of Corporate Conduct, 90 YALE L. J. I (1980) (recommending that the control of corporate organizations be accorded the concentrated attention of an independent field of law).

15. E. Redrord, Administration of National Economic Control (1952); R. Lan'illetiti, M. Hamilton, R. Roberts, Phase II in Review; The Price Commission Experience (1975). See also 12 U.S.C.A. $\$ 1904$ note.

16. See Carstensen, Antitust Law, Competition, and the Macroeconomy, 14 U. MICH. J. L. REF. 173 (1981).

17. Bennett \& Sharpe, supra note 5, at 179. E. White, Control or Restrictive Business Prac:TICES IN LATIN AMERICA 31 (1975).

18. Constitution of Mexico, Art. 28 (English translation in 9 Constitutions of The Countrits () THE WORLD Mexico-16 (A. Blaustein, G. Flanz eds. 1980)) [hereinafter cited as Mexican Constitution].

19. Organic Law Implementing Article 28 of the Constitution Concerning Monopolies (Aug. 31, 1934) (English translation, as amended in UNITED NATIONS CONFERENCE ON TRADE AND DH:VEICPment, Control of Restrictive Trade Practices in Latin America Adpendum 58-62 (1975)) (hereinafter cited as Mexican Monopoly Law]. 
provision appears to be largely unenforced; ${ }^{20}$ however, other economic regulations reflect a concern for a competitive market context for private economic activity. ${ }^{21}$

While the three countries substantially agree on the primacy of the market as the means to organize economic activity, the consensus favoring an indirectly regulated and competitive market over a market whose ultimate performance is directly controlled, (or over no regulation) is less strong. Two arguments independently support a conclusion that perfecting the competitiveness of markets ought to be the primary approach to any policy of economic integration.

First, based on historic experience, a competitive market, pushed or pulled by subsidy, protection and supplemental regulation of specific transactional concerns, has proven to be the most efficient and effective way to organize economic forces. ${ }^{22}$ Such a market frees private will to act and react so that hope of private gain will induce desired economic activity. ${ }^{2: 3}$

The second basis for preferring competition as the primary policy objective is that, in seeking economic integration of three quite different economies at different stages of economic development, a great deal of decision-making will have to remain at the national level. Such national decisions can more easily fit into an overall context of competition among enterprises in the three economies than can fit into a collective performance-regulating scheme which seeks to control specific outcomes in markets.

Such a competitive market cannot exist, however, without affirmative government action. At the very least, courts must be told when and how restrictive contracts may or may not be enforced. The corporation is a legal creation. All its actions, especially merger, can occur only because government gives it the legal right. More comprehensively, the legal system makes choices, consciously or not, to create and to limit legal rights. Those choices must inherently affect the degree of competition which occurs in the market. Consequently, if a competitive market is the objective sought, the law must be developed in ways consistent with that objective.

These arguments point toward an overall policy which seeks to promote and maximize competition in the context of economic integration. In general, the more procompetitive a solution is, the more it should be favored, provided it also substantially achieves its other objectives. Promoting competition directly, only to frustrate it unnecessarily by other policies, is unproductive. This is not to say that, in developing environmental or consumer protection policy, some competitive effect will not occur. Rather it is to urge that such effects be taken into account, and

20. E. White, supra note 17.

21. See Foreign Investment Code, supra note 4, especially art. 13; Law of 28 December 1972 Conccrning Registration of Transfer of Technology and the Use and Working of Patents, Trade-Names and TradeMarks (English translation in United Nations Conterknce on Trade and Deveiopment, Controm. OF Restrictive Trade Practices in Latin America Addendum 173-76 (1975)) [hereinafter cited as Technology Transfer Law]; see also, Note, Uniled States Antitrust Lawes and Mexican Foreign Investment Late's: A Comparative Survey, 13 Houst. L. REv. 571 (1976); E. WhITE, supra note 17.

22. C. LinDBLOM, supra note 1 .

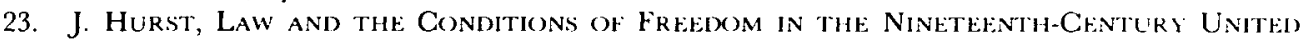
States (1956). 
that alternatives be sought which achieve the maximum in competition while serving the primary objective.

A second policy implication beyond the specific scope of this discussion is that an important objective in integrating economic activities should be the perfection of markets which are presently not functioning as efficiently as possible. ${ }^{24}$ Such market-perfecting regulation includes information disclosure requirements (so that buyers can make informed judgments) and market-organizing regulation, which acts to create sufficiently large or informed buyers or sellers.

II

\section{The Substantive Law of Competition}

Substantive law of competition is divisible into three basic areas: monopoly, restrictive conduct and merger. The following subsections consider each of those subject areas.

\section{A. Monopoly}

The acquisition or retention of a monopoly position in any line of business creates grave risks to the efficient operation of a competitive market system. A monopoly unfettered by the contraints of the market is free to set price, quality and output to serve its own interest. It affects both present efficient use of resources by charging excessive prices, and future development of an economy by its efforts to entrench and protect its position.

The creation and maintenance of monopoly can involve conduct aimed at destroying actual or potential competitors by means other than acceptable competition. In addition, in seeking to maximize monopoly profit or entrench its position, a monopolist may inflict unnecessary harm on firms operating in other related markets. At the same time, the hope of a monopoly is a lure that induces investment, invention and desirable competitive activity, as the patent laws illustrate. Consequently, an inherent tension exists in the law governing monopoly between a desire to be rid of monopoly and a recognition that much monopoly is either desirable or, at least, unavoidable. The current state of monopoly law in Canada, Mexico and the United States provides some indication of the difficulties in finding a suitable resolution to that tension.

American law seeks both to eliminate monopolistic structural conditions and to forbid undersirable monopolistic conduct. ${ }^{25}$ In broad brush strokes, the American rules governing monopolistic conduct regulate three aspects of monopolistic behavior: (1) the use of existing monopoly power to obtain a position in another market, (2) the exploitation of monopoly power to achieve monopoly profits, and (3) the scope of permissible conduct in defending or acquiring a monopoly position. In general, a monopolist may not use its monopoly position directly to

24. Cf. Reich, Toward a New Consumer Protection, 128 U. PA. L. REv. I (1979).

25. A part of the problem in American law may be that a single statutory provision, Section 2 of the Sherman Act, 15 U.S.C. $\S 2$ (1976) provides the legal basis for both structural and conduct cases despite the substantial differences between the specific legal theories and the remedies that are involved. 
achieve a position in another market. ${ }^{26}$ A firm with a not unlawful monopoly is generally free to charge whatever it wishes for goods or services over which it has a monopoly; ${ }^{27}$ it may not, however, exploit its market power in ways which directly affect competition in other markets. ${ }^{28}$ The hardest set of rules to define govern the rights of firms to engage in conduct which creates or protects a monopoly. Some situations are clear, e.g., excluding a competitor by compelling a boycott. ${ }^{29}$ Such situations involve the use of market power only to cause harm to others. When a monopolist responds to new competition with price cuts or other traditionally competitive conduct, deciding whether and when such conduct is wrongful is very difficult. Given its existing or potential power in the market, a monopolist has an incentive to protect its position through intensely competitive conduct only because of the expected future dominance and exploitation of the market. Such conduct, while competitive on its face, is not reasonable in competitive terms. On the other hand, any rule which substantially restricts the freedom of a monopolist to compete can create an undesirable "umbrella" over inefficient competitors and deny the economy the advantages of competition. ${ }^{30}$ Consequently, efforts to define "predatory" practices have not achieved consistent results or rules."

The second line of American legal development, elimination of structural monopoly, has sought to define criteria under which a firm with a monopoly position may be dissolved. Two theories of liability have emerged. One requires proof of abusive conduct by a monopoly as a predicate to structural relief. ${ }^{32}$ Such evidence may serve a function beyond creating a threshold condition for liability in that it may demonstrate that the continued existence of a monopoly which has had to behave in such a way to survive is not economically necessary in efficiency terms. The second theory holds that possession and conscious retention of monopoly power are sufficient to constitute a violation. ${ }^{33}$ Implicitly, this second approach also requires that the plaintiff show that a structural remedy is available. It would make no sense to declare unlawful that which is unremediable. ${ }^{34}$

26. This is part of the rationale for tying law. See Northern Pacific Ry. Co. v. United States, 356 U.S. 1, 6 (1958). It is also the basis for such decisions as Uniled States v. Griffith, 334 U.S. 100 (1948).

27. This is most obvious in the case of a clearly lawful monopoly such as a patent. The price charged for a patented good, however high, will not in itself constitute abuse of the patent. Of course, such prices, in cases where a monopoly is not per se lawful, may be substantial evidence of monopoly and consequently a party with such power may itself be an unlawful monopoly. That is a proposition distinct from the lawfulness of the price charged.

28. Northern Pacific Ry. Co. v. United States, 332 U.S. 1 (1958); International Salt Co. v. United States, 332 U.S. 392 (1947); LaPeyre v. FTC, 366 F.2d 117 (5th Cir. 1966). See Carstensen, Annual Survey of Antitust Developments, 1976-1977, 35 WASH. \& LEE L. REV. I, 38-45 (1978)

29. Lorain Journal Co. v. United States, 342 U.S. 143 (1951).

30. See, In re Borden, 92 FTC 669, $817-32$ (1978) (Pitofsky, Comm., concurring).

31. The debate over the definitions of predatory pricing is illustrative of the problems. For a comprehensive set of citations and useful discussion see McGee, Predatory Pricing Revisited, 23 J. L. \& ECON. 789 (1980).

32. United States v. United Shoe Machinery Corp., 110 F. Supp. 295, 341-43 (D.C. Mass. 1953), affd per curiam, 347 U.S. 521 (1954).

33. United States v. Grinnell, Corp., 384 U.S. 563 (1966); United States v. Aluminum Co. of Amcrica, 148 F.2d 416 (2d Cir. 1945).

34. The recent FTC decision on DuPont's monopoly in titanium dioxide illustrates the confusion resulting from mixing the abusive conduct theory with the structural theory of monopoly. Although apparently no structural remedy was sought, the complaint counsel relied on the Alcoa and Crinnell cases, 
In both lines of cases it is not easy to determine when a firm has sufficient market power to be classified as a monopoly. The problem arises because many firms have some market power, but it is sufficiently limited so that it would be unfair either to call the firm an unlawful monopoly or to label use of the economic power as an abuse of monopoly power. The absence of a clear line for division means that specific cases can involve ad hoc decisions.

Canada has had specific antimonopoly legislation since 1910, but the statute is a criminal one. ${ }^{35}$ Not only does the criminal standard of proof apply, but the target of the statute is only abuse of monopoly position in a market "either to create or protect a monopoly position." 36 The efforts to enforce this law have been few and have frequently resulted in victory for the defendant. ${ }^{37}$ Much of the ineffectiveness of this law stems from the judicially imposed requirement that there be proof of specific instances of public detriment. The conscious acquisition of a monopoly position, not justified by efficiency and achieved by easily reversable merger, is not an unlawful act. ${ }^{38}$ Recently, the Canadian Parliament considered but did not adopt substantial amendments to its antitrust laws which, inter alia, would have provided a more effective antimonopoly provision. ${ }^{39}$ The proposal would have both redefined the offense and made it a civil one enforceable through injunction and dissolution by an administrative agency. ${ }^{40}$

The Mexican Constitution of 1917 prohibits private monopoly. ${ }^{41}$ The 1934 statute implementing and defining these prohibitions ${ }^{42}$ has apparently never been enforced directly. ${ }^{43}$ The intent of the statute is to prohibit possession of monopoly and its abuse, but its remedy provisions apparently provide only for performance regulation of a monopolist's prices, output and dealings with third parties and do not provide for dissolution of a monopoly. ${ }^{44}$

Control over monopoly also comes from the laws regulating technology trans$\mathrm{fer}^{45}$ and foreign investment in Mexican industry. ${ }^{46}$ Both statutes have protection-

supra note 33, to argue the unlawfulness of the monopoly in the absence of any abuse. The FTC, in rejecting this argument, went too far in questioning Alcoa and Grinnell's validity in true structural cases. In re DuPont, 96 FTC 650 (1980).

35. Combines Investigation Act, Can. Rev. Stat. c. C-23, Part II (as amended)(1970); Rosenbluth, Monopoly and Monopolization, in Canadian COMPetTtion POLICY, supra note 12, at 330-35.

36. Id. at 331 .

37. Rosenbluth, supra note 35 , reports only two monopoly investigations and no prosecutions before World War II and only seven suits and four additional investigations in the almost three and a half decades since the war.

38. Regina v. K.C. Irving Ltd., 62 D.L.R. (3d) 157, affd, 72 D.L.R. (3d) 83 (1976).

39. See Rosenbluth, supra note 35 , at $336-40$.

40. It does appear that such remedies exist under the present law despite its overtly criminal character. Thus in the lroing case, the trial judge, having found a criminal monopolization, ordered divestiture. Regina v. K.C. Irving Ltd., 45 D.L.R. (3d) 45 (1974) (criminal conviction) 22 C.C.C.(2d) 281 (New Bruns. S.C.t. 1974) (divestiture order), conviction rev'd, 62 D.L.R. (3d) 157 (1975), affd, 72 D.L.R. (3d) 821 (1976). See Combines Investigation Act, CAN. REV. STAT. c. C-23, 30(2) (1970).

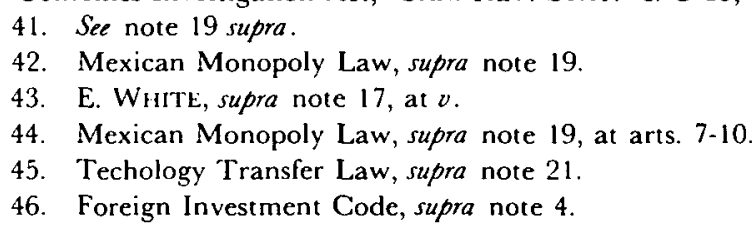


ist overtones ${ }^{47}$ whose constitutionality might be questionable, ${ }^{48}$ but they also identify and implement competitive mandates. The technology transfer law treats such transfers as sales, thereby ensuring the recipient the future right to use the acquired technology ${ }^{49}$ It also restricts sales conditions which would limit future competition in domestic or international markets, or which would exploit the monopoly power of the seller in the markets for other goods or services. ${ }^{50}$ Consistent with the performance regulation of the monopoly statute, the Ministry of Industry and Trade also reviews the fairness of the price charged for such technology. ${ }^{51}$ This direct regulation, however, has as an objective the creation of an international market in technology which would provide a self-policing quality to prices for such service. ${ }^{52}$

The initial question for an integrated North American economy is the scope of monopoly control. Should such control exist? If so, should it cover only abusive conduct or should it reach and try to remedy structural monopoly as well? The laws of Canada, Mexico and the United States are unanimous on the proposition that monopoly must be subject to legal control. Such a conclusion seems required by a commitment to the creation and preservation. of a competitive market system. There is also substantial agreement that efforts to expand monopoly directly into new markets and to exploit monopoly by conduct affecting other markets are unacceptable abuses of monopoly power ${ }^{53}$ All three countries also condemn the use of predatory conduct to acquire or retain a monopoly. ${ }^{54}$ The problem, as American experience illustrates, is in defining predation beyond the obvious cases of purely anticompetitive conduct. Despite their arbitrariness in some contexts, explicit rules establishing standards for minimum prices in relation to cost and other similar situations may be the only way to reach a consensus on this topic. An important consideration is whether such rules would have a pre-emptive effect over more restrictive national laws when applied to transactions between countries.

In evaluating the need for regional rules dealing with structural monopoly, one factor is the number of significant monopolies amenable to structural remedy which exist on a regional basis. If the number is small, the existence of merger,

47. Katz, Mexico's Import Licensing Strategy for Prolecting Import Replacements: An Aspect of Trade Policy and Planning For Industy Development, 33 AM. J. ECON. \& SOC. 381 (1974).

48. See Notc, supra note 21 , at 572 n. 8 (1976).

49. Camp \& Magnon. Recent Developments Under the Mexican Foreign Investment Law and the Lau" Regulating the Transfer of Technology, 8 LAWYER OF THE AMER ICAS 1, 16 (1975).

50. Technology Transfer Law, supra note 21 , at art. 7.

51. Id., at art. 7, II (if price for technology is "disproportionate, the agreement is void). See Camp \& Magnon, supra note 49 , at $17-19$.

52. Proof of a prevailing world price for a technology and prices for substitutes will justify specific prices for licenses. The effect of the collection and presentation of such information is to educate both regulators and buyers as to alternatives. Camp \& Magnon, supra note 49, at 19.

53. This argument rejects the contentions of some that tying and other similar conduct promotes efficiency. See, e.g., Bowman, Tying Arrangements and the Leverage Problem, 67 YAl.E L. J. 19 (1957).

The American courts presented with this argument have correctly concluded that any arguable efficiency can in most cases be achieved in other less anticompetitive ways. See e.g. International Salt Co. v. United States, 332 U.S. 392 (1947); IBM v. United States, 298 U.S. 131 (1936).

54. See notes $26,28,29,36,45,46$ supra. 
abusive conduct and restraint-of-trade rules may suffice. The most likely sources of regional monopoly power are the natural resource industries, but these industries are the ones which both Canada and Mexico propose to control via public ownership. The establishment of rules governing the means by which such economic enterprises, if monopolistic, must interact with customers is probably tolerable to national sensitivity; however, prohibiting monopoly ownership of such resources is less likely to be acceptable. Yet, national ownership is consistent with competitive market structure. Multiple entities, each independent of the others, can exist even if ultimate ownership rests in a national trust. ${ }^{5.5}$ Any necessary coordination or regulation can come from an overtly regulatory agency.

From an enforcement perspective, structural relief is frequently the best and most efficient way to remedy both structural and abusive monopoly. Decrees that establish anti-abuse standards are frequently either ineffective or cause substantial inefficiency. ${ }^{56}$ The very difficulty in defining workable rules to govern predation suggests the potential utility of an approach which removes the need to solve an intractable problem. One possible solution would be to authorize a regional agency which in addition to enforcing its own monopoly controls, could invoke the law of the nation where a monopolist's assets are situated. Under such a scheme, assets located in America would be much more vulnerable to a structural remedy than would those based in Canada or Mexico. This approach has the virtue of an added remedy which is consistent with the solution which the relevant national law would have conferred.

\section{B. Restrictive Conduct}

Typically, laws governing competition seek to regulate several types of situations. First, there is conduct which is undesirable whether displayed individually or collectively, and whether or not the perpetrator has any appreciable market power. Such offenses include false advertising, deceptive selling practices and price discrimination. All three countries already have similar rules forbidding such conduct. ${ }^{57}$ Because of their orientation toward final consumers, most of these rules can remain largely the province of national or local law as long as they apply equally to all actors in the specific marketplace.

Price discrimination rules may require some greater regional consensus. Both America and Canada adopted statutes in the 1930s which forbid price discrimination and which have similar substantive prohibitions. ${ }^{58}$ Mexican law would

55. The Mexican experience with its general state investments is illustrative. See Bennett \& Sharpe, supra note 5, at 174-179 (state equity investments made through several independent agencies).

56. Cf. In re Borden, 92 FTC at 817-32. Especially undesirable are the performance regulating types of remedy envisaged in the Mexican antitrust statute. See Mexican Monopoly Law, supra note 19, at art. 28. More administrable and less intrusive are decrees which specify when and how a firm may use its market power.

57. Compare Benitz, Inter-American Legal Developments, 8 LAWYer (of THE AMERICAS 399, 433-34 (1976) (summary of recodified Mexican consumer protection laws) with Leaffer and Lipson, Consumer Actions Against Unfair or Deceptive Acts or Practices: The Private Uses of Federal Trade Commission Jurisprudence, 48 GeO. WAsh. L. ReV. 521, 524-38, 560-64 (1980) (summary of state and Federal law) and Belobaba, linfair Trade Practices Legislation: Symbolism and Substance in Consumer Protection, 15 Oscioone HAl.L. L. J. 327 (1976).

58. Compare Combines Investigation Act, Can. Rev. Stat. c. C-23 $\$ 34$ (1970) with 15 U.S.C. $\S \S 13$, 
appear to share a similar general rejection of price differences not cost justified. ${ }^{59}$ Given these national laws, the question remains whether price differences between national markets ought to be the object of regional concern. To the extent that such conduct attempts to protect or create monopoly, standards created for the control of monopoly conduct would apply. Even where monopoly is not a possible outcome, conduct which exploits differing market demand can produce negative effects on both consumers who pay higher prices and competitors who confront lower prices. Yet, such price variances are crucial signals to the market to direct the allocation of production and investment. For this reason economic logic commands that neither price differences alone be condemned nor regionwide price uniformity (adjusted for transit and other cost variances) be required.

Logically, the role of price in a market economy suggests that price differences ought not to be objectionable unless the difference is likely to cause significant anticompetitive effect to competitors, customers or suppliers of the firm engaging in this conduct. This approach, already employed in American and Canadian law, acts to constrain the pricing freedom of firms to ensure that they do not inflict gratuitous economic harm on others as they respond to supply and demand changes in the market.

The second major category of conduct is that which is objectionable because it is the result of collective action. This is classically referred to as contract, combination or conspiracy in restraint of trade. Such combinations may have two quite different functions with respect to restraint. They may aim at creating or preserving market power by collective action aimed at destroying the competitive capacity of third parties. (This may be called collective predation.) Alternatively, combinations may aim to exploit, for the benefit of the participants, market power which those participants have already created individually or collectively. (This may be called exploitative conduct.) Combinations may engage in both types of conduct.

A second distinction among collective actions is often useful. Some collective conduct involves only attempts to achieve or exploit power, nothing more. Thus, two or more competitors might agree to divide a market, freeing each from competition. Alternatively, such conduct can involve, at least arguably, an effort to achieve some objective in addition to that of restraint; such restraint is, at least in part, a functional incident to the achieving of that primary goal. All such agreements constitute restraints, but their function is arguably quite different. The jurisprudential utility of this distinction is that, whereas the reasonableness of the first class of restraint (pure or naked restraint of trade) is determinable only by reference to the reasonableness of the end result (a diminution of competition), the

13a (1936). The Canadian law is only criminal while the American law is both civil and criminal. Scction 2 of the Robinson-Patman Act, 15 U.S.C. $\S 13$, condemns conduct only civilly while Section 3,15 U.S.C. $\S 13 \mathrm{a}$, is on its face criminal, but is enforceable civilly both in private actions, 15 U.S.C. $\S \S 14 \& 21$ (damages and injunctions), and in government civil suits, 15 U.S.C. $\S 20$. See Comment, Resale Price Maintenance in Canada and the United States, 4 TEx INT'L L. F. 156 (1968); Thompson, Resale Price Maintenance and Refusal to Sell: Aspects of Problem in Competition Policy, 21 U. TORONTO L. J. 67 (1971).

59. Technology Transfer Law, supra note 21 , at art. $7 ; f$. Mexican Monopoly Law, supra note 19 , at art. $5($ ii). 
reasonableness of the second class (ancillary restraints) is measurable by reference to the need for the restraint to achieve the primary objective. Thus, in this second class of cases, a court can make a focused factual examination of the relationship between restraint and objective and inquire whether some lesser degree of restraint could have achieved the same primary objective. Employing this kind of analysis provides a consistent method of weighing competitive policy against specific efficiency justifications for suppressing competition in particular instances. By way of contrast, there is no consistent standard for judging the reasonableness of the first category of restraint. ${ }^{60}$

The American approach to collective restraint is stringent. The law applies to all agreements to restrain without regard to effect. ${ }^{61}$ All naked restraints, of which cartels are one illustration, are illegal per se. ${ }^{62}$ American courts have gone beyond this rule to condemn as presumptively illegal combinations which had apparent ancillary defenses. ${ }^{63}$ Recent decisions have retreated and extended the reasonableness test to more instances, ${ }^{64}$ but in at least some situations the presumption of illegality remains. ${ }^{65}$ American courts have, however, removed from antitrust perview collective restrictive conduct when that conduct is subject to specific governmental control and review. ${ }^{66}$

In Canada, restraint of trade law has been inconsistent in its treatment of collective conduct. Canadian law requires that the prosecutor first establish that a restraint has had an "undue" effect. ${ }^{67}$ The consequence is that conduct which is fundamentally without competitive or efficiency justification is allowed to occur because of the failure to satisfy this irrelevant requirement. ${ }^{68}$ Thus, even a cartel may defend itself as not "undue." 69 In addition, the Canadian courts have developed no guidelines to inform business when such cartel exploitation of power will or will not be undue. In contrast to these ambiguous rules, Canada also has a statute which condemns vertical price agreements as illegal per se apparently without regard to any ancillary justification. ${ }^{70}$ From this one may infer that there is no

60. Bork, The Rule of Reason and the Per Se Concept, Pt. I, 74 YAle L. J. 775 (1965).

61. Plymouth Dealers Ass'n of N. Cal. v. United States, 279 F.2d 128 (9th Cir. 1960).

62. See National Soc'y of Professional Eng'rs v. United States, 435 U.S. 679 (1978).

63. See, e.g., United States v. Topco Associates, 405 U.S. 596 (1972); Albrecht v. Herald Co., 390 U.S. 145 (1968); United States v. Arnold, Schwinn \& Co., 388 U.S. 365 (1965).

64. See, e.g., Broadcast Music, Inc. v. Columbia Broadcasting System, Inc., 441 U.S. 1 (1979); Continental TV Inc. v. GTE Sylvania Inc. 433 U.S. 36 (1977), rev'g Arnold, Schwinn \& Co. v. United States, supra note 63 .

65. See, e.g., Catalano,Inc. v. Target Sales, Inc. 446 U.S. 643 (1980)(per curiam); California Retail Liquor Dealers v. Midcal Aluminum, Inc., 445 U.S. 97 (1980).

66. Bates v. State Bar of Arizona, 433 U.S. 350 (1977); National Ass'n of Securities Dealers v. United States, 422 U.S. 694 (1975).

67. Combines Investigation Act, Can. Rev. STat. c. C-23 $\S 32$ (1970). See Note, R. Abitibi, A Reconsideration of the "Per Se" Doctrine under the Combines Investigation Act, 10 MCGill. L. J. 385 (1964).

68. One amendment to Canadian law may have had the effect of requiring more evidence of actual effect. Brecher, Combines and Competition: A Re-Appraisel of Canadian Public Policy, 38 CAN. BaR. REv. 523, 590-91 (1960).

69. See Atlantic Sugar Refineries Co. v. Att. Gen. of Canada, 54 C.C.C. (2d) 373, (Can. S.Ct. 1980) (tacit agreement lessened competition but this was not undue).

70. Combines Investigation Act, Can. Rev. Stat. c. C-23 $\$ 38(3)$ (1970). See Comment, Resale Price Maintenance in Canada and the United Stales, 4 TEx. INT'L. L. F. 156 (1968). 
fundamental objection to a rule which generally forbids naked restraints. ${ }^{71}$

Mexican law also has sanctions against collusive restrictive behavior. Here, the rules apply to restrictive terms in contracts by which technology is imported into the country. ${ }^{72}$ Restrictions on the buyer's subsequent use of that technology are generally forbidden. Thus, these rules are aimed primarily at predatory contract restraints. The Mexican Constitution and antitrust statute also suggest opposition to exploitative restraints. ${ }^{73}$ Given the substantial direct control over prices, a lesser concern to prohibit agreements to engage in exploitative conduct is understandable.

At a very general level, a consistent policy against restraints of freedom of traders to make their own decisions exists in all three countries. Unfortunately, some restraints may be the unavoidable incident of achieving efficient integration of productive or distributive processes. Two approaches are feasible. First, the countries could forbid collective conduct of specific sorts unless registered and approved. The bases for approval should be spelled out in terms of effects on competition, efficiency gains and effects on designated common interests or values. Such a system could approve restraints whether predatory or exploitative, naked or ancillary. The approving agency would retain power to order revision of the agreements whenever the public interest required and could also review specific decisions or conduct pursuant to such agreements. The model of registration, approval and continuing regulation is that found in the European Economic Community treaty and, to some extent, in Mexican law. ${ }^{74}$

The second alternative is the American and Canadian approach which creates general prohibitions on classes of restraints. The defense of state action limits that prohibition. Thus, where a member country makes an affirmative decision favoring noncompetition in a particular area, and such a decision is not ultra vires, the restraints are immune from antitrust sanction. ${ }^{75}$

The latter approach still leaves open the question of the criteria for judging those restraints which government action does not immunize. From Taft's opinion in United States $v$. Adyston Pipe $\mathcal{E}$ Steel $\mathrm{Co}^{76}$ to the present, American judges and commentators have generally endorsed the idea that judging the reasonableness of an action intended only to eliminate competition (e.g., a cartel) is not feasible. Canada's history of trying to perform this analysis suggests that such a conclusion is entirely justified. Therefore, if the decision is to subject all restrictive agreements

71. The unfortunate statutory language and judical confusion as to what constitutes an agreement in some situations complicates the general trend in this direction. See Brecher, supra note 68; Reschenthaler $\&$ Stanbury, Oligopoly and Conscious Parallelism: Theory, Policy and the Canadian Cases, 15 OsGOODE HAL1. L. J. 617 (1977); Note, supra note 67

72. Technology Transfer Law, supra note 21, at art. 7.

73. Mexican Monopoly Law, supra note 19; Mexican Constitution, supra note 18, at art. 28.

74. See Mexican Monopoly Law, supra note 19; Technology Transfer Law, supra 21, at art. 8.

75. Cf. Silver v. N.Y. Stock Exch., 373 U.S. 341 (1963) (specific delegation to private decisions of power without regulatory review immune from antitrust review so long as conduct confined to the specific authorization); Bates v. State Bar of Ariz., 433 U.S. 350 (1977) (restraints not subject to antitrust law because subject to continued state administrative review).

76. United States v. Addyston Pipe \& Steel Co., 85 F. 271 (6th Cir. 1898), modified $\mathcal{G}^{\circ}$ affd 175 U.S. 211 (1899) 
(except those protected by state action) to after-the-fact review, the American model of per se illegality for all naked restraints and a rule based on the ancillarity and resulting reasonableness of any restrictiveness in any other agreement would appear to be the most feasible approach. This approach does not entirely forbid purely anticompetitive agreements. It does remit such conduct to the legislative process at the outset. The legislature can determine whether or not such restriction is in the public interest and, if so, it can impose whatever public interest review is suitable for the situation.

The second approach also minimizes the need for continual public involvement in and review of business decisions. A system of registration and prior approval inherently involves the assigned agency in a continual process of bargaining with business over the exact nature of each collective agreement. This often produces extensive regulation of internal business affairs-conduct which serves no useful social purpose. Moreover, such intervention might adversely affect the dynamic vigor of business enterprise. ${ }^{77}$ If a robust, competitive and dynamic economy is the ultimate objective, the proper stance of antitrust should be as little intervention as is feasible.

Experience with public utility regulation suggests that public agencies will not or cannot administer private restraints in the public interest. Indeed, the recent deregulation of American banking, air travel and ground transportation was aimed at freeing huge industries from inefficient cartel constraints imposed by government regulators nominally in the public interest. These considerations point toward a preferrence for the second approach in dealing with combinations in restraints of trade.

\section{Merger}

Canada, Mexico and the United States all recognize that mergers, as well as other acquisitions of corporate or other business assets, are events which can be and, in some circumstances, ought to be objects of government regulation. In the United States such regulation is almost exclusively based upon competitive considerations. The only generally applicable statutory control is that of the Clayton Act, which forbids mergers that may tend to lessen competition or to create a monopoly. ${ }^{78}$ The result has been a judicially mandated set of rules which create presumptive condemnation for vertical and horizontal mergers involving more than minimal market shares. ${ }^{79}$ Combinations involving less direct likelihood of competitive effect, i.e., mergers involving conglomeration or potential competition, are generally lawful absent proof of a significant specific likelihood of anticompetitive effect. ${ }^{80}$

The Canadian and Mexican concern with merger is quite different. Canada

77. B. Klein, Dynamic Economics (1977).

78. 15 U.S.C. $\$ 15$ (1976).

79. Brown Shoe Co. v. United States, 370 U.S. 294 (1962); United States v. Philadelphia Bank, 374 U.S. 321 (1963); United States v. Continental Can Co., 378 U.S. 441 (1964). But see, e.g., United States v. General Dynamics Corp., 415 U.S. 486 (1975) (presumption overcome on facts of case).

80. See, e.g., FTC v. Proctor \& Gamble Co., 386 U.S. 568 (1967); FTC v. Consolidated Foods Corp., 380 U.S. 592 (1965). Many major mergers are never even challenged. See, e.g., Kraar, General Electric 's Very 
presently has a crimninal statute outlawing merger which lessens or is likely to lessen competition "to the detriment . . . of the public. ${ }^{81}$ Only six prosecutions have occurred under this provision, from its adoption in 1910 to 1978 , and the government lost all of the cases. ${ }^{82}$ In order to prevail the government must show not a risk of monopoly prices but a risk of specific harmful effect. ${ }^{83}$ Mexican law is even less clear on this point, but the 1934 statute's prohibition of anticompetitive agreements could arguably reach anticompetitive mergers and acquisitions. ${ }^{84}$ In contrast, both countries subject acquisitions of domestic businesses by foreign interests to explicit and extensive review. ${ }^{85}$ In part, the motivation for such review is whether competition is served. Thus, such acquisitions are objectionable in those instances where they may have anticompetitive effect. ${ }^{86}$

The size of the Mexican and Canadian economics is crucial to an understanding of the lack of strong domestic merger control. Neither economy is nearly as large as that of the United States. The economic arguments for merger, i.e, that it permits efficient consolidation of productive resources, make far more sense in the context of small markets than in a market of more than 200 million consumers. ${ }^{87}$ Consequently, the policies governing isolated national economics do not necessarily suggest that similar policies would govern if the economic context were larger.

Assuming a policy in which mergers are regulated for competitive reasons, a primary source of guidance will be the American experience. There is, however, no consensus on the merits of the American merger law. Critics suggest that the connection between market structure and conduct is a very weak one, so that inhibiting consolidation in fact has little or no effect on conduct variables such as price cost margins. ${ }^{88}$ Critics are even more hostile toward attempts to control mergers when the firms are not actual or potential competitors. Thus, vertical mergers are said to produce no change in market structure, and so involve no

Personal Merger, Fortune, Aug., 1977, at 187 (describing GE-Utah Mining Merger worth several billion dollars).

81. Combines Investigation Act, CaN. Rev. Stat. c. C-23 $§ 2$ (1970).

82. Stanbury, Stage /I Amendments: An Overview in Canadian Competition Policy, supra note 12, at 55,62 .

83. See Regina v. K.C. Irving Ltd., 45 D.L.R. (3d) 45 (1974); Regina v. Canadian Breweries Ltd., 126 C.C.C. 133 (Ont. High Ct. 1969); Reschenthaler \& Stanbury, A. Clarification of Canadian Merger Policy, 22 Antitrust Bull. 673 (1977); Roberts, The Death of Competition Policy: Monopoly, Merger and Regina v. K.C. Irving Lid., 16 UNIV. WEst. ONT. L. REv. 215 (1978).

84. Mexican Monopoly Law, supra note 19, at art. 4(ii). See also, id. at art. 4(i), (iii).

85. See Foreign Investment Code, supra note 4 (Mexico); Foreign Investment Act, supra note 10 (Canada).

86. Foreign Investment Code, supra note 4, at art. 13(x), (xiii) (Mexico); Foreign Investment Act, supra note 10 , at $\S 2(2)$ (c)(Canada). The primary purpose is however to protect and promote domestic ownership. There is also in these laws regulation of foreign de novo entry, which has a stronger aspect of protectionism for local businesses.

87. Canadian evidence is, however, that these effects do not occur. Thompson, Mergers, Effects, and Competition Policy: Some Emperical Evidence, in Canadian Competition Policy, supra note 12, at 297-328. This failure is partly explained by the advantage of retaining local monopoly often in conglomerate form. See Leff, 'Monopoly Capilalism' and Public Policy in Developing Countries, 32 KrKLOS 718 (1979).

88. Demsetz, Two Systems of Belief About Monopoly, in Industrial Concentration: The New Learning 164 (H. Goldschmid, H. Mann \& J. Weston eds. 1974). 
appreciable risk to competition. ${ }^{89}$ Similarly, conglomerate mergers, which involve no existing or potential market relationships between the combining firms, arguably involve no immediate appreciable competitive risks. ${ }^{90}$ Other schools of thought hold that expansive antimerger rules have been a significant factor since the mid-1950s in the preservation of fairly constant or even slightly declining levels of concentration in specific markets, and that this has in turn produced a more competitive and dynamic economy than might otherwise have existed.91

Despite this controversy, it is clear that American antimerger policy has had no substantial negative effect on efficiency. The critics argue only that the rules have not acted to enhance competition. Some, simplistically, then conclude that such rules must have anticompetitive effect. But both Canadian and American analysts have convincingly demonstrated that many mergers occur for reasons other than efficacy, ${ }^{92}$ and no direct evidence of inefficiency resulting from forbidden mergers exists. In at least one industry, an observer has suggested that the effect was positive. ${ }^{93}$

Given the small effect of merger on competition and economic efficiency, one might conclude that this aspect of economic behavior can be ignored. Still, if no law existed, late 19th-century American and more recent Canadian experience suggests that merger to monopoly or oligiopoly could occur. So long as national laws are left in place and firms freely compete in all three nations, the result will be that American antimerger law will have a dominating effect on the overall reorganization of assets by merger. However, the better course would be to provide explicit regional merger rules. Expanding the size of the competitive market is at the core of the desirability of economic integration; since it is generally agreed that merger can produce anticompetitive results, some control is desirable. This is especially true where some of the nations involved have policies forbidding or controlling foreign acquisition of domestic assets and where some mergers in one country could have their primary competitive effect in other countries. One major advantage of an agreement on merger is that it could designate those classes of mergers (e.g., mergers involving enterprises having substantial assets in, or whose business significantly affects, more than one country of the group) to which such rules would apply.

Any merger rule would have to include a ban on mergers among substantial competitors within the region in the absence of a compelling justification. ${ }^{94}$ Rules

89. Bork, Vertical Integration and the Sherman Act: The Legal History of an Economic Misconception, $22 \mathrm{U}$ Chi. L. ReV. 157 (1954).

90. E.g., Coase, Working Paper for the Task Force on Productivity and Competition: The Conglomerale Merger, 115 ConG. ReC. 15938 (1969).

91. Mueller, The Celler-Kefauver Act: The First 17 Years, Subcomm. On Monopolits and Commtkcial Law of the House Comm. on the Judiciary, 95th Cong., 2d Sess. (Comm. Print 28, 1978).

92. See Thompson, Mergers, Efect, and Compelition Policy: Some Emperical Evidence, in CanadIan Compttition Policy, supra note 12, at 297; P. Steiner, Merciers: Motives, Erfects, Policies (1975)

93. Elzinga, The Beer Industry in StruCTURE or AMERICAN Industr y 189, 202-03 (4th ed. W. Adams 1971).

94. Compelling justification tests, when rigorously enforced, rarely result in the allowance of mergers. See e.g., Citizens Publishing Co. v. United States, 394 U.S. 131 (1969) (rejecting failing firm defense because other buyers existed); United States v. Third Nat'l Bank in Nashville, 390 U.S. 171 (1968) (rejecting convenience and needs defense for bank merger). 
barring substantial vertical combinations while somewhat questionable in static economic theory, have the effect of creating added incentives for new vertical expansion, which tends to produce larger numbers of competing firms and to maximize competition in intermediate stage markets. The basic approach that American experience suggests is to condemn all mergers above stated guideline market shares unless a compelling justification is proven. ${ }^{95}$ Introducing more extensive specific analysis of individual mergers will produce little useful refinement in thinking or analysis but will entail great delay, confusion and obscurity. ${ }^{96}$

Also worth consideration would be two rules, one which would bar combinations between large firms engaged in the same or similar activities even if not competitiors at the time of merger and another which would forbid the merger of very large enterprises regardless of competitive effect. The first proposal would govern the area now encompassed by the ineffective potential competition doctrine. ${ }^{97}$ In moving to a more integrated North American economy, many firms will confront competition, actual or potential, from new sources. During the evolution of this new expanded market, it is especially desirable that large firms be notified that they can neither conspire with nor merge with emerging competitors in order to suppress the potential for more vigorous competition.

The second suggested rule forbidding mergers of large enterprises aims at conglomerate mergers and has both economic and political justification. Economically, such a rule acts to direct investment toward new enterprise and away from mere acquisition. ${ }^{98}$ It also acts to increase the aggregate number of economic actors aiding the overall dynamics of the economy. ${ }^{99}$ As a political matter, this rule keeps economic power more decentralized, thus at least marginally protecting the political order from undue distortion. ${ }^{100}$

\section{The Source and Shape of Regional Antitrust Policy}

The foregoing suggestions have repeatedly urged the adoption of key aspects of American antitrust doctrine as basic regional policy. While in part this may reflect the bias and limitation of one knowledgeable primarily in that system, it is also true that America has had the broadest and most intensive experience with antitrust law. Moreover, America's vast size and wealth provide a better approximation to the regional market being considered than do those of Mexico or Canada.

If American antitrust law is a key inspiration, it need not be slavishly followed.

95. United States v. Philadelphia Nat'l Bank, 374 U.S. 321 (1963); United States v. Continental Can Corp. 378 U.S. 441 (1964). See also United States v. General Dynamics Corp., 415 U.S. 486 (1974).

96. For one such proposal, see Quinn, Institutional Design and Canadian Merge Policy in Canadian ComPETITION POLICY, supra note 12, at 269. The problem with employing such a multifactor analysis particularly when the factors are unweighted and subjective, is that specific results can and will appear random.

97. United States v. Marine Bar Corp., 418 U.S. 602 (1974); BOC Int'l Ltd. v. FTC, 557 F2d 24 (2nd Gir. 1977); R. Posner, Antitrust Law: An Economic Perspective, 113-25 (1976); Bradley, Polential Competition Mergers: A Structural Synthesis, 87 YALE L. J. 1 (1977).

98. See Leff, supra note 87.

99. B. KLEIN, supra note 77.

100. Blake, Conglomerate Mergers and the Antitrust Laws, 73 Colum. L. REv. 555 (1973); Carstensen \& Questal, The Use of Section 5 of the Federal Trade Commission Act to Altack Large Conglomerate Mergers, 63 CoRNELL L. REV. 841 (1978). 
Thus, although American courts employ rules of presumptive illegality against all horizontal agreements regardless of their ancillarity and condemn vertical price fixing, there is no reason to expand the application of these rules to the region as a whole. Similarly, the American challenge to purely structural monopoly is not an essential element in a regional antitrust policy.

The central organizing principle of American antitrust law is an incompletely articulated ideal that a society dependent upon voluntary market transactions should never tolerate the private creation, possession or retention of more economic power than is reasonably necessary to achieve productive efficiency. Thus, restrictive agreements which act only to create or regulate market power are illegal per se, while all others are judged by the necessity for their anticompetitive effect in achieving economic efficiency. In monopoly, the same pattern obtains: conduct whose primary function or effect is to disrupt competition in other markets or to eliminate competition within a market is always objectionable and is fundamentally without excuse or justification. Only when the conduct at issue achieves socially useful results does the process of evaluation become more difficult. Finally, in the merger area, rules which forbid the merging of large firms draw substantial support from repeated theoretical and empirical studies which show that negative efficiency effects are very unlikely. At the same time, an antimerger policy keeps the economic power inherent in large business enterprise dispersed.

The central principle of limiting market power and forbidding its gratuitous creation implies that there must be rules of broad inflexible prohibition on conduct whose only function is to achieve such ends. All three countries agree on the fundamental truth of this proposition; it is in both statutory and decisional application where confusion and deviation have emerged. Only if the central principle of regulating a competitive market economy is recognized and consistently implemented will the advantages of such a market flow in the optimal degree and direction.

\section{III}

\section{Enforcement of Regional Competition Policy}

The choice of methods for enforcement of regional competitive policy is likely to produce as much disagreement as do the substantive rules. The enforcement problem involves many choices, one of which concerns the character of the public enforcement agency or agencies: should there be a regional agency or should national agencies undertake this additional burden? Another important choice involves the method by which policy will be enforced; this includes the choice between administrative and judicial enforcement modes, as well as the choice between criminal and civil liability. There is the question of the relationship between regional enforcement and national enforcement programs, as well as the relationship between national programs. Another question concerns the creation of some regional forum to review decisions, however made, which affect regional interests. There is the choice of role for private litigation: should regional law allow such actions; if so, should the plaintiff be entitled to injunctive or damage relief; and if damage relief is available, how should it be measured? Existing 
choices among the three countries show a lack of consensus on all of these issues. The following discussion can raise only some of the enforcement concerns.

\section{A. Public Enforcement}

Three of the issues previously identified involve the public enforcement of competition policy. The most basic question is who will perform this function. The obvious alternatives are the existing national agencies or a new regional agency. Inherently, enforcement of regional policy on competition will require a broad regional view of competitive effects and is likely to entail conflict with powerful economic interests in the several countries. In addition, a significant aspect of implementing regional policy may well involve advocacy of regional competitive policy to national agencies; this is a difficult burden to assign to national agencies. Finally, it is doubtful that Mexico presently employs an agency with a mandate confined to enforcing competitive policy as such. All of these reasons suggest the creation of a regional enforcement agency.

A regional agency need not be large. Its size and scope would be a function of the rules which it is to enforce. Many of the policies and rules that any regional agency would implement would also be the subject of parallel action by national agencies. In such cases, the regional agency need play only a secondary role to insure that regional policies are properly considered. Another issue involves the operation of the enforcement process. The choice is between a rule-oriented and at least quasi-judicial proceeding ${ }^{101}$ or a nonadversarial administrative approach similar to the Mexican administative procedures.

Use of the adversarial rule-based approach permits employing a professional judiciary to decide specific cases. Job security and separation from immediate political concerns would allow such decision-makers, if properly informed, ${ }^{102}$ to apply policy more effectively than administrative agency members whose tenure and position is directly subject to political control. A select group of skillful and knowledgeable judges can handle such cases in more neutral and therefore acceptable terms.

As long as the focus of an enforcement agency is restricted to the promotion of a competitive policy, the adversarial approach is preferable; however, at a regional level, there must also be a balance between promotion of competition and other concerns such as promotion of technological development, protection of specific politically favored economic interests, or reallocation of wealth, ownership or control of productive assets. The balancing of such concerns is not feasible in a judicial forum. The Mexican model of agencies, which draw their leadership from a range of key ministries and then make political-administrative determinations based on nonadversarial proceedings, constitutes the proper model for such a balancing task.

101. The American system employs the FTC, an administrative agency, and the Justice Department, but both operate within a quasi-judicial, rule-oriented framework. Canadian law enforcement is somewhat similarly structured.

102. The Canadian experience demonstrates the risks of an ill-informed judicary. See Roberts, supra note 83; Reschenthaler, supra note 71. 
It is questionable, however, whether such integration should occur at the ad hoc level of particular case decisions. To bring the Mexican approach, based on a small economy, a strong central government and a limited private arena, to a regional administration would be doubtful as an efficient administrative choice and as a sound political strategy. When specific decisions take account of too many divergent policies, observers get the impression of either randomness or arbitrariness in policy execution. To assure public support and effective policy implementation enforcement, agencies need fairly clear mandates. The integration of competition and other policies should occur in the legislative context, which must remain flexible and responsive.

One other argument favoring administrative over judicial enforcement deserves brief mention. An administrative regime can handle regulation of cartel or other naked restraints in a way which judicial processes cannot. To the extent that the substantive rules allow cartel behavior some administrative regime will be essential.

Although an adversarial rule-oriented approach to competition can employ criminal as well as civil sanctions, it would not be advisable to employ overtly criminal sanctions in a regional enforcement program. Great difficulty arises in defining criminal conduct, as the earlier substantive discussion showed; many actions and situations are undesirable only some of the time. Moreover, civil penalties and injunctions can achieve most of what criminal sanctions could accomplish. This is especially true if firms are also subject to national law sanctions.

Lastly, there is the question of who will review decisions. If an adversarial approach is employed, the arena would expand to include the making of such initial decisions. Clearly, several possibilities exist: cases could be heard or reviewed in national courts; a new regional judiciary could be created, possibly drawn from the judiciary of the participating countries; or, especially if initial decisions are administrative, review could be in some legislative or executive political forum. Providing for judicial review seems preferable because it ensures that specific matters will be decided pursuant to explicit rules. Political review can occur through rule changes which could have retroactive effect. In addition, public enforcement efforts through governmental agencies would themselves be subject to political control. Even if the basic enforcement process is nonadversarial, with attendant political review, judicial review remains feasible to test the consistency of a specific decision with general rules and policy. ${ }^{103}$ This suggests that some regional judicial review exist, not only in cases involving review of a regional enforcement agency, but also in cases from national courts involving significant regional issues. If such a court is not needed for regional purposes, it could most easily be created from panels of judges drawn from the national judiciaries.

\section{B. Private Actions}

A second major enforcement subject concerns the role of private parties as di-

103. See D. Barounos, D. Hall, J. James, EeC antitrust law Principi.es and Practicie ch. 12 (1975); Smit, Recent Developments in the EEC-Antitust and the Court of Justice 28 AM. J. COMP. L. 334 (1980). Cf. Board of Governors of Fed. Reserve Sys. v. First Lincolnwood Corp., 439 U.S. 234 (1978). 
rect litigants. Through a variety of informal means, private parties can seek to have public agencies invoke the law against competitors, suppliers and customers to whose conduct they object. Such solicitation may not be adequate. It filters through a review process which has a stated and actual concern to promote the public interest in the matters it reviews, but the public interest in challenging conduct devastating to an individual firm may be slight. Moreover, enforcement priorities and the personal views of the leadership of the public agency and its staffio4 will help determine which cases receive attention. Finally, the pyramidal character of public decision-making means all final decisions must pass through a very limited number of top officials. Such a process can slow down the speed of action.

Comparison of Canadian and American experience demonstrates the implications of limiting enforcement to public agencies. While in neither country is public litigation frequent, ${ }^{105}$ antitrust rules are more effective in America because of the private rights of actions. No one decision-maker or organization has a monopoly over implementing the statutory commands. Indeed, Canadian policy analysts have identified the lack of significant private rights of action as a primary reason for the underdevelopment of Canadian competition law. ${ }^{106}$

Critics of private antitrust enforcement assert that the private cause of action includes many incentives which are not consistent with the public interest objectives of antitrust law. ${ }^{107}$ To a significant extent, reformulation of private actions can ensure that private interest in litigation does correspond to a public interest in preserving or promoting competition. For example, American courts are now formulating more exactly the entitlement to damages guaranteeing a closer relationship between the right to damages and the underlying anticompetitive conduct. ${ }^{108}$ In addition, public agencies can affect private litigation through intervention in cases in an effort to advise the court of their views. Such intervention provides the judge with a more complete range of alternatives and a more dispassionate analysis of the merits of the matter. This is especially important in matters of remedy.

On balance, the advantages of allowing private actions appear to outweigh the disadvantages. The contrast between the United States and Canada strongly supports the conclusion that effective implementation of competition policy requires much policing of the market. Creating carefully defined private actions will facilitate this greatly. Any significant reliance on private action for enforcement would require that regional competition policy be codified in the form of rules and not

104. The role of staffs in controlling antitrust agency conduct is discussed in $\mathrm{S}$. WEAVER, DECISION to Prosecute: Organization and Public Policy in the antitrust Division (1977). See also R. Katzman, Regulatory Bureaucracy: the Federal Trade Commission and antitrust Policy (1979).

105. Gorecki \& Stanbury, Canada's Combines Investigation Act: The Record of Public Inw Enforcement, 18891976 in Canadian Competition Policy, supra note 12, at 135; Posner, A Statistical Siudy of Antitrust Enforcement, $13 \mathrm{~J}$. L. \& ECON 365 (1970).

106. McDonald, Private Actions and the Combines Investigation Act in Canadian Competition Poilicr, supra note 12, at 195; Prichard, Privale Enforcement and Class Actions in Canadian Competition P(OLIC:;, supra note 12 , at 217 .

107. W. Breit \& K. Elzinga, The Antitrust Penalties: A Study in law and Economicis, $63-$ 76 (1976).

108. See Page, Antitust Damages and Economic Efficiency: An Approach to Antitrust Injury, 47 U. CHI. L. REv, 467 (1980). 
left to nonadversary administrative actions. Thus private enforcement does tend to push the choice of general public enforcement toward the adversarial model.

Private enforcement need not necessitate a regional forum; it would be possible to leave such claims to national courts. The regional agreement would define the scope of private claims for violation of the regional rules, giving national courts the duty of implementation. This solution is attractive because, in many instances, claims might be made under national law as well, at least, if the action arose in the United States or Canada. The only necessary limitation to national court disposition is that rulings applying substantive standards of liability or remedy ought to be reviewable by some regional judicial agency.

What damages should a regional private damage right provide? American law provides for trebling. ${ }^{109}$ The rationale for this is deterrence. The prospect of losing three times the gain or the harm to the victim (whichever is greater), should eliminate most incentives to engage in such conduct, as long as an actor believes that there is a reasonable likelihood of being detected. The most valid criticism of the treble damage rule arises when it is invoked to challenge behavior which had not previously constituted a violation of antitrust law, or when the judgment of violation emerged only after a careful and close assessment of the reasonableness of specific behavior. The unfairness of the trebling in these contexts is that its deterrent effect is aimed at conduct which may well not need deterring or may create a general paralysis of will among businesses.

An alternative to eliminating treble damages entirely would be to set some limits to the situations in which such a rule could be invoked. Selective denial of trebling might provide reasonable assurance to potential defendants without seriously impairing the effectiveness of the overall deterrent. Such denial could occur where the defendant makes a convincing showing of the novelty of the plaintiff's theory or of the general reasonableness of his own conduct, even if in some specifics the result was to violate the law. Such an exemption from trebling would not do away with the duty to pay actual damages.

Despite the deterrent value of treble damages, it appears unlikely that such a remedy would be authorized as a matter of regional agreement. Again, as long as national law rights remain unimpaired, most regional offenses would also offend American law and theréfore, to at least some degree, would be subject to treble damage claims.

Should private parties be allowed to seek injunctive relief in addition to damages? The primary risk here is that such relief creates a temptation to seek anticompetitive outcomes. At the same time, if private parties have the right to obtain prospective relief, it is easier to refuse damages in close cases. Ensuring that a proposed injunction is itself procompetitive and not anticompetitive requires a reasonable degree of judicial sophistication in administering relief. The public agency could also review any settlement or injunctive proposal affecting future competition. 


\section{Relating National and Regional Laws and Enforcement}

American antitrust law asserts the right to reach transactions in foreign countries which affect American commerce. ${ }^{110}$ Such extraterritorial jurisdiction is the source of conflicts between the United States and other countries, including Canada. Canada has adopted laws which limit both investigation and ultimate liability of Canadian enterprises for what America would regard as a violation of its law. ${ }^{111}$ One issue which regional integration must resolve is the allocation of enforcement rights in such situations.

Presumably, the presence of a regional enforcement system, employing agreedupon policies, ought to provide a substitute for some extraterritorial national action. This raises the question of the jurisdictional limits for the regional agency. The deeper the agency's penetration into matters which only affect regional commerce indirectly, the greater the need for a detailed reconciliation of policy objectives. Practical politics suggests that jurisdiction of the regional agency and regional rules should be limited to situations that directly involve the flow of goods or services between member countries.

There is also the problem of relating national and regional enforcement. Rules of either primary or exclusive jurisdiction are needed. A primary-jurisdiction approach would establish a sequence of review over a situation with both national and regional agencies having vetoes. Approval would require that all affected agencies acquiesce. Exclusive jurisdiction would assign complete decisional authority to one level, preempting all others. Exclusive jurisdiction is not inconsistent with active participation by other agencies in the designated forum. The strongest objection to a general rule of exclusive jurisdiction is the great difficulty in assigning unambiguous authority. Transactions of regional interest inherently involve multiple claims of legitimate right to review. This suggests that a primaryjurisdiction approach may generally be the more feasible alternative. Still, in cases where a situation involves firms the bulk of whose assets are located in a single country but whose conduct significantly affects other jurisdictions, it may be necessary to preempt any extraterritorial jurisdictional claim for the laws of the nondomicile (but affected) jurisdiction, and to allow primary jurisdiction to rest in the regional agency and confer secondary jurisdiction with the domicile. Such an approach ought to resolve some of the conflicts between America and Canada. One implication of this approach is that private actions would also be limited to domicile or regional claims. Where there are American victims of Canadian or Mexican anticompetitive conduct, a limitation of existing rights would result. In employing a primary-jurisdiction approach, difficult situations could develop where national and regional interests conflict. Ultimately, regional agreement will determine the scope of rights to act which are contrary to common policy. But within any such right, the regional competition agency can undertake a program of advocacy and education to persuade national agencies to select those alterna-

110. United States v. Aluminum Co. of Am., 148 F.2d 416, 443-44 (2d Cir. 1945); W. FUGATE, FOREign COMMERCE and THE ANTITR USt Laws (2d ed. 1970).

111. See Antitrust \& Trade Reg. Rep. (BNA) (No. 973) A-19 (1979). 
tives which are more consistent with regional policy. Thus, to the extent that nations retain the right to reject nonnational buyers of domestic enterprises or entrants into domestic business, those rights ought to be exercised in accord with preserving and promoting regional competition. The regional competiton agency is a well-located advocate for such a viewpoint.

\section{IV}

\section{CONCLUSion}

The problems of creating a common North American policy on competition and antitrust are many. This review suggests that the greater problems are more likely to emerge in selecting the instruments of enforcement and in relating competition policy to existing controls over markets, than in the selection of substantive rules. There may, nevertheless, be a temptation in creating agreement to try indirectly to achieve that which could never be accomplished directly: the elimination of controls over the competitive market. This temptation must be resisted. A functionally competitive market is fragile and continually threatened. It can not flourish without an explicit effort to ensure its existence. Regional economic integration which failed to provide effectively for such protection would, in the long run, fail to produce the economic advantages which it could achieve. 
